\title{
Sistem Pertandaan Semiotik Pada Iklan Layanan Masyarakat “ Stop Hoax" Dalam Media Televisi Indosiar (Analisis Semiotik Jhon Fiske)
}

\author{
Siroy Kurniawan \\ Universitas Islam Negeri Sunan Kalijaga Yogyakarta \\ Email: siroykurniawan@gmail.com
}

\begin{abstract}
Hoak News becomes a news story that has an element of lies. The rise of hoax news caused considerable concern for the community. For that a media provides education through advertising. Ads that are loaded are not advertisements as usual which only promote goods. Public Service Ads provide education in this case education about Hoax news. To find out more about the signs in Stop Hoax advertisements, the author uses the semi-physical analysis of John Fiske's model which consists of levels of realization, representation and ideological level. The results of the analysis at the reality level illustrate how the atmosphere of the morning rush so that negligence occurs until the event wants to drink vehicle cleaning fluid. At this level it produces a form of expression and a residential environment. At the level of representation describes how to take significant pictures then plus the backsoun music that is used and the overall color effect present how the consequences that occur in the ad. Level three ideology, the ideology used in the advertisement is how advertising can package an information in the form of public service advertisements.
\end{abstract}

Keywords: Advertising, Semiotics, Stop Hoaxes

\begin{abstract}
Abstrak
Berita Hoak menjadi sebuah kabar berita yang memiliki unsur kebohongan. Maraknya berita hoax menimbulkan kekawatiran yang cukup mendalam bagi masyarakat. Untuk itu sebuah media memberikan edukasi melalui iklan. Iklan yang dimuat bukan iklan seperti biasa yang hanya mempromosikan barang. Iklan Layanan Masyarakat memberikan edukasi yang dalam hal ini edukasi mengenai berita Hoax. Untuk mengetahui lebih dalam mengenai pertandaan dalam iklan Stop Hoax penulis menggunakan analisis semiotika model John Fiske yang terdiri dari level realistas, repsentasi dan level idiologi. Hasil analisis tersebut pada level realitas menggambarkan bagaimana suasana kesibukan pagi hari sehingga terjadi keteledoran hingga peristiwa ingin minum cairan pembersih kendaraan.
\end{abstract}


Pada level ini menghasilkan bentuk ekspresi serta lingkungan perumahan. Pada level representasi menggambarkan bagaimana pengambilan gambar yang signifikan kemudia ditambah backsound music yang digunakan serta efek warna yang keseluruhan mempresentasi bagaimana kondisi yang terjadi dalam iklan tersebut. Level ke tiga ideologi, ideologi yang di pakai dalam iklan tersebut bagaimana iklan mampu mengemas sebuah informasi dalam bentuk iklan layanan masyarakat.

Kata kunci : Iklan, Semiotika, Stop Hoax

\section{A. Pendahuluan}

Di zaman ini teknologi berkembang semakin pesat. Perkembangan ini ditandai dengan munculnya berbagai macam alat elektronik yang mewarnai kehidupan masyarakat sejak abad ke-20 hingga sekarang. Munculnya berbagai macam alat elektronik yang tercipta dari tangan-tangan ilmuan memudahkan masyarakat dalam mencari informasi ataupun berkomunikasi. Sudah bukan menjadi hal tabu, jika pengguna media elektronik ini mulai dari anak-anak hingga orang dewasa menggunakannya untuk kebutuhan yang mereka perlukan.

Dewasa ini iklan digunakan untuk mempromosikan suatu produk yang dihasilkan dari sebuah industri atau perusahaan. Iklan memiliki peran yang sangat besar dalam mempengaruhi khalayak. Iklan mampu menciptakan sebuah pesan untuk ditampilkan kepada kahalayak dan mampu mempengaruhi persepsi mereka. Pesan para pengiklan ada di mana-mana. Semua ini muncul dalam bentuk billboard, di radio, televisi, di bus, dan kereta bawah tanah, di majalah dan surat kabar, di poster, di pakaian, sepatu, topi, dan pena, daftar ini bisa diperpanjang terus. ${ }^{1}$ Selain digunakan untuk pemasaran produk, iklan juga digunakan untuk memberikan efek positif dalam kehidupan. Seperti iklan yang ditayangkan dalam media televisi yang dipersembahkan oleh stasiun TV Indosiar.

Iklan yang dimuat dalam TV tersebut berjudul "Stop Hoax". Dari iklan tersebut menanamkan nilai moral dan sosial terutama dalam bidang bersosial media. seperti kita ketahui penggunaan media saat ini terkadang cenderung berbau negative. Menyebar kebohongan dan fitnah terkadang kerap dilakukan oleh media, hanya untuk mendapatkan reting tinggi dan penghasilan berlebih.

Sungguh disayangkan jika media hanya dijadikan sumber penghasilan tersendiri, dengan menyebarkan berita bohong atau iklan-iklan yanhg berbau isu sara. Iklan "Stop Hoax" ini dirasa mampu memberikan padangan baru mengenai problematika kehidupan saat ini. Melihat fenomena mengenai berita bohong yang kerap terjadi menjadikan semakin bobroknya

1 Marcel Danesi, Pengantar Memahami Semiotika Media (Ypgyakarta: Jalasutra, 2017),.221. 
media dalam mengemas berita. Dalam pandangan Islam yaitu al-Qur'an juga telah menyebutkan berkaitan berita bohong dalam :

Hai orang-orang yang beriman, jika datang kepadamu orang fasik membawa suatu berita, maka periksalah dengan teliti agar kamu tidak menimpakan suatu musibah kepada suatu kaum tanpa mengetabui keadaannya yang menyebabkan kamu menyesal atas perbuatanmu itu. (al-Hujarat: 6)

(Hai orang-orang yang beriman! Jika datang kepada kalian orang fasik membawa suatu berita) (maka periksalah oleh kalian) kebenaran berita itu, apakah ia benar atau berdusta. Menurut suatu qiraat dibaca Fatatsabbatun berasal dari lafal At-Tasabaat, artinya telitilah terlebih dahulu kebenarannya (agar kalian tidak menimpakan musibah kepada suatu kaum) menjadi maful dari lafal Fatabayyannu, yakni dikawatirkan hal tersebut akan menimpa musibah pada suatu kaum (tanpa mengetahui keadaannya) menjadi hal atau keterangan keadaan Fa'il, yakni tanpa sepengetahuan (yang menyebabkan kalian) membuat kalian ( atas perbuatan kalian itu) yakni berbuat kekeliruan terhadap kaum tersebut (menyesal) selanjutnya Rasullullah Saw, mengutus Khalid kepada mereka sesudah mereka kembali ke negrinya. Ternyata Khalid tiada menjumpai mereka melainkan hanya ketaatan dan kebaikan belaka, lalu ia menceritakan hal tersebut kepada Nabi Saw. ${ }^{2}$

Maksudnya telitilah berita itu dengan cermat, tidak tergesa-gesa menghukumi perkara dan tidak meremehkan urusan,sehingga benar-benar menghasilkan. Berita yang perlu dikonfirmasi adalah berita penting, ditunjukan dengan digunakannya kata Naba' untuk menyebut berita, bukan kata kabar. Al-Qur'an memberi petunjuk bahwa berita yang perlu diperhatikan dan diselidiki adalah berita yang sifatnya penting. Adapun isu-isu ringan, omongan kosong, dan berita yang tidak bermanfaat perlu diselidiki, bahkan tidak perlu didengarkan karena hanya akan menyita waktu dan energi.

Dalam era informasi saat ini, mudah sekali orang percaya dan menyebar-yebarkan kabar berita yang tidak jelas asal dan sumbernya dari mana. Lebih parah lagi dengan adanya aplikasi gadget seperti Facebook, Youtube, What Apps, dll. Setiap orang sring kali mem-broadcast berita yang isinya sampah, hoax dan menyesatkan. Terkadang isinya tidak saja kabar yang belum tentu kebenarannya, tetapi juga hadis-hasdis lemah (dha'if) dan palsu (maudhu) banyak menyebar dan malah edit, dibuat-buat untuk menakut-nakuti.

Dalam penelitian mengenai pemaknaan moral dalam iklan Stop Hoax peneliti menggunakan analisis semiotika Jhon Fiske yang mempunyai tiga level yang menjdi satu kesatuan dan tidak dapat dipisahkan. Diantaranya realiti, representasi dan ideologi.

${ }^{2}$ https://tafsirq.com/49-al-hujurat/ayat-6 dimuat pada 2015 


\section{B. Landasan Teori}

\section{Analisis Semiotika}

Semiotika adalah ilmu yang mengkaji tanda dalam kehidupan manusia. Artinya, semua yang hadir dalam kehidupan kita dilihat sebagai tanda, yakni seuatu yang harus di beri makna. Semiotic adalah studi tentang tanda-tanda. Konsep tanda ini untuk melihat bahwa makna muncul ketika ada hubungan antara ditanda in absentia (Signified) dan tanda (Signifier). Tanda adalah kesatuan dari suatu bentuk penanda (signifier) dengan sebuah ide atau penanda (signified). Dengan kata lain, penanda adalah "suara berarti" atau "makna graffiti". Semiotika adalah studi tentang tanda-tanda (sign), fungsi tanda, dan produksi makna. Tanda adalah sesuatu yang berarti sesuatu untuk orang lain. Studi semiotic tandatanda, penggunaan tanda dan segala sesuatu yang berkaitan dengan tanda. ${ }^{3}$

Semuotika menurut Jhon fiske ada;ah studi yang mempelajari tentang tanda-tanda, juga tanda-tanda dalam film. Jhon Fiske sendiri mengatakan bahwa pusat dari konsentrasi semiotika adalah tanda-tanda, kajian mengenai tanda dan cara tanda-tanda tersebut bekerja.

\section{Komunikasi Massa}

Komunikasi massa merupakan salah satu topik diantara sekian banyak topic lainnya dalam ilmu social. Komunikasi massa merupakan bagian dari ilmu komunikasi yang lebih luas, yaitu komunikasi manusia (buman communication). Berger dan Chaffe mendefinisikan ilmu komunikasi sebagai pengetahuan yang berupaya memahami produksi, proses dan efek dari sistem symbol dan tanda dengan mengembangkan teori-teori yang dapat diuji, berisi generalisasi hokum yang menjelaskan gejla-gejala yang berhubungan dengan produksi, proses dan efek. ${ }^{4}$

Janowitz menyatakan bahwa komunikasi massa terdiri atas lembaga dan teknik dimana kelompok-kelompok terlatih menggunakan teknologi untuk menyebarluaskan simbol-simbol kepada audience yang tersebar luas dan bersifat heterogen. Definisi Janowitz ini berupaya untuk menyamakan kata 'komunikasi massa' dengan pengiriman (transmisi) pesan yang hanya menekankan pada aspek pengiriman saja, definisi ini tidak memasukan aspek respons dan interaksi. ${ }^{5}$ Karakteristik Komunikasi Massa menurut para ahli sebagai berikut:

${ }^{3}$ Jafar lantowa, Nila mega marahayu, Muh.Kharussibyan, Semiotika teori,metode dan penerapannya (Yogyakarta: CV Budi Utama, 2017), 3.

${ }^{4}$ Morissan, Andy Corry Wardhani, Farid Haid U, Teori Komunikasi Massa (media, budaya dan masyarakat) (Bogoor: Ghalia Indonesia,2013),.5

${ }^{5}$ Morissan, Andy Corry Wardhani, Farid Haid U, Teori Komunikasi Massa (media, budaya dan masyarakat), 7-8 
1. Komunikator Lembaga

Ciri utama komunikasi massa adalah komunikator mengatas namakan lembaga. Komunikatornya merupakan individu yang menjadi bagian dari tim atau sistem. Wartawan, penyiar, dan presenter menulis berita, siaran, dan membawa acara atas nama lembaga mediannya.

2. Pesan Umum

Pesan komunikasi yang disampaikan melalui media massa adalah terbuka untuk semua orang. Benda-benda tercetak, film, radio dan televise apabila dipergunakan untuk keperluan pribadi dalam lingkungan yang tertutup, tidak dapat dikatakan komunikasi massa.

3. Komunikan Heterogen

Komunikan dalam komunikasi massa adalah sejumlah orang yang disatukan oleh suatu minat yang sama yang mempunyai bentuk tingkah-laku yang sama dan terbuka bagi pengaktifan tujuan yang sama; meskipun demikian orang-orang yang bersangkutan tadi tidak saling mengenal, berinteraksi secara terbatas, dan tidak terorganisasikan.

4. Serempak

Keserempakaan yang dimaksud ialah keserempakan kontak dengan sejumlah besar penduduk dalam jarak yang jauh dari komunikator, dan penduduk tersebut satu sama lain berada dalam keadaanterpisah. Radio dan televise dalam hal ini melebihi media cetak.

5. Hubungan non-pribadi

Sifat non-pribadi ini timbul disebabkan teknologi dari penyebaran yang massal dan sebagaian lagi dikarenakan syarat-syarat bagi komunikator yang bersifat umum.

6. Bersifat satu arah

Dalam komunikasi massa, sebenarnya antara komunikator dengan komunikan yang berperan aktif, namun keduannya tidak bisa berdialog atau berkomunikasi secara langsung, seperti yang terjadi pada proses komunikasi antar personal. Hal inilah yang membuat komunikasi massa ini bersifat satu arah.

7. Umpan Balik yang Tertunda

Hal tersebut dikarenakan prosesnya yang tidak secara langsung bertatap muka antara komunikator dan komunikan. Feedback dari komunikasn dapat dilakukan menggunakan pesawat telepon, email, sms dll (itu dikatakan tertunda atau tidak langsung). ${ }^{6}$

6 https://www.komunikasipraktis.com, dalam kajian komunikasi-massapengertian, pada /2015/04/.html 


\section{Televisi}

Televisi saat ini telah menjadi bagian tak terpisahkan dari kehidupan manusia. Banyak orang yang menghabiskan waktunya lebih lama didepan pesawat telebisi dibandingkan dengan waktu yang digunakan untuk mengobrol dengan keluarga atau pasangan mereka. Bagi banyak orang TV adalah teman, TV menjadi cermin prilaku masyarakat, dan TV dapat menjadi candu. TV membujuk kita untuk mengkonsumsilebih banyak dan bayak lagi. TV memperlihatkan bagaimana kehidupan orang lain dan memberikan ide tentang bagaimana kita ingin menjalani hidup ini. Ringkasnya TV mampu memasuki relung-relung kehidupan kita lebih dari yang lain. ${ }^{7}$

Sejarah mencatat sejak pemerintah membuka Televisi Republik Indonesia (TVRI) pada tanggal 24 Agustus 1962, maka selama 27 tahun penotnon televise di Indonesia hanya dapat menonton satu saluran televise.

Pada tahun 1989, pemerintah memberikan izin oprasi kepada kelompok usaha Bimantara untuk membuka stasiun televisi ECTI yang merupakan televise swasta pertama Indonesia. Gerakan reformasi pada tahun 1998 telah memicu perkembangan industri televisi, sehingga televisi merupakan medium terfavorit bagi para pemasang iklan, dank arena itu mampu menarik investor untuk membangun industry televisi. Media televisi merupakan industry yang padat modal, padat teknologi dan padat sumber daya manusia. ${ }^{8}$

\section{Iklan Televisi}

Iklan atau Advertising dapat diartikan sebagai bentuk komunikasi non personal mengenai organisasi, produk, servis atau ide yang dibayar oleh suatu sponsor yang diketahui. Iklan mengandung (4) empat aspek yaitu : (1). Berita atau pesan (2.) barang atau jasa (3). Penonton (4). Media massa. Secara umum iklan di media televisi dikelompokan dalam 2 (dua) tujuan : (1). Iklan Komersial (2). Iklan layanan Masyarakat (LSM) Bentuk iklan dalam media televisi terbagi menjadi tiga bagian yaitu: (1). Sponsorship (2). Iklan partisipan (3). Iklan Barter. ${ }^{9}$

\section{Iklan}

William Sprigel memberi pedoman tentang periklanan bahwa periklanan adalah "Any paid from of non-personal presentation of good or ideas to a grub" (setiap bentuk yang dibayar dari penyampaian non personal dari pada barang jasa kepada kelompo).

${ }^{7}$ Morissan, Jurnalistik. Televisi Mutakbir (Jakarta: Kencana, 2008), 1

${ }^{8}$ Ibid, 3 televisi/2019

${ }^{9}$ https://www.sarifudn.com/penyiaran/indek.php/siaran-televisi/2-iklan- 
Berdasarkan definisi diatas, dapat disimpulkan bahwa tujuan utama iklan adalah memberitahukan (to Infrom), membujuk (to persanade), dan dengan bentuk komunikasi lain yaitu:

a. Gagasan, barang, dan jasa. Iklan identic dengan promosi barang dan jasa, namun tidak menutup kemungkonan jika iklan merupakan perwujudn dari sebuah gagasan atau ide seperti yang terjadi dalam iklan layanan masyarakat yang mengangkat masalah social.

b. Khalayak/ non personal, khalayak yang diterpa iklan bersifat heterogen dan berbeda karakteristik satu dengan lainnya.

c. Sponsor, lembaga yang membiayai iklan merupakan lembaga yang dapat mempertanggung jawabkan apa yang ditawarkan kepada calon konsumen sehingga membuat iklan berbeda dengan propaganda.

d. Pembayaran, iklan yang ditampilkan dimedia dipungut pembayaran kepada lembaga yang memasangkan iklan tersebut. ${ }^{10}$

\section{Iklan layanan masyarakat}

Iklan layanan masyarakat (ILM) dapat dikampanyekan oleh organisasi profit atau non profit dengan tujuan social eonomis yaitu meningkatkan kesejahteraaan masyarakat. Iklan layanan masyarakat (public service announcement) biasa dimuat atas pemerintah atau lembaga swadaya masyarakat (LSM) untuk menggalang solidaritaas masyarakat atas suatu masalah. Masalah maslaah ketertiban, lalu lintas, program pemerintah dan lain-lain.

Menurut Liliweri pengertian iklan layanan masyarakat adalah jeis iklan yang bersifat non-profit. Jadi iklan ini tidak mencari keuntungan akibat pemasangan kepada khalayak. Iklan layanan masyarakat menurut suanto adalah pengumuman tentang berbagai pelayanan masyarakat, tidak disebarluaskan melalui pembelian ruang dan waktu serta setiap kegiatan pelayanan masyarakat dilaksanakan oleh suatu kegiatan non-profit/tidak mengejar keuntungan. ${ }^{11}$

\section{Metode Semiotika Jhon Fiske}

Jhon Fiske berpendapat bahwa tiga bidang studi utama dalam semiotik, yaitu:

1. Tanda itu sendiri, terdiri atas tentang berbagai tanda.

2. Kode atau sistem yang mengorganisasikan tanda, mencakup cara berbagai kode di kembangkan guna memenuhi kebutuhan suatu masyarakat atau budaya untuk mengeksploitasi saluran komunikasi yang ada.

10 Ade Putri, "Representasi Agama dalam Iklan Indonesia adalah kita di NET.TV”, ejurnal Ilmu Komunikasi, vol. 55. 2018.

${ }^{11}$ Ibid 
3. Kebudayaan tempat kode dan tandabekerja, penggunaan kode-kode dan tanda-tanda untuk keberadaan dan bentuknya sendiri.

Menurut John Fiske dalam Eriyanto, proses representasi ada tiga yaitu :

1. Level pertama, adalah peristiwa yang ditandakan (encode) sebagai realitas. Bagaimana peristiwa tersebut dikonstruksi sebagai realitas oleh wartawan/media. Dalam bahasa gambar (terutama televisi) ini umumnya berhubungan dengan aspek pakaian, lingkungan, ucapan, dan ekspresi. Di sini, realitas selalu siap ditandakan, ketika kita menganggap dan mengkonstruksi peristiwa tersebut sebagai sebuah realitas.

2. Level kedua, ketika kita memandang sesuatu sebagai realitas, pertanyaan berikutnya adalah bagaimana realitas itu digambarkan. Disini kita menggunakan perangkat secara teknis. Dalam bahasa tulis, alat teknis itu adalah kata, kalimat atau proposisi, grafik dan sebagainya. Dalam bahasa gambar/ televisi, alat itu berupa kamera, pencahayaan, editing, atau musik. Pemakaian kata-kata, kalimat, atau proposisi tertentu, misalnya membawa makna tertentu ketika diterima oleh khalayak.

3. Level ketiga, bagaimana peristiwa tersebut diorganisir ke dalam konvensi-konvensi yang diterima secara ideologis. Bagaimana kodekode representasi dihubungkan dan diorganisasikan kedalam koherensi sosial seperti kelas sosial, atau kepercayaan dominan yang ada di dalam masyarakat(patriarki, materialisme, kapitalisme, dan sebagainya. ${ }^{12}$

\section{Metode Penelitian}

\section{Jenis Penelitian}

Penelitian ini menggunakan penelitian kualitatif yang bersifat deskriptif analisis, penelitian kualitatif adalah penelitian yang bersifat interpretif (menggunakan penafsiran) yang melibatkan banyak metode dalam menelah masalah penelitiannya. Peneliti kualitatif lazim menelaah hal-hal yang berada dalam lingkungan alamiahnya, berusaha memahami, atau menafsirkan fenomena berdasarkan makna-makna yang orang berikan kepada hal-hal tersebut. ${ }^{13}$

12 Eriyanto, Analisis Isi: Pengantar Metodologi untuk Penelitian Ilmu Komunikasi dan Ilmu-ilmu Sosial Lainnya, (Jakarta: Kencana, 2011), 114

13 Dedy Mulyana dan Solatun, Metode Penelitian Komunikasi (Bandung: PT Remaja Rosdakarya, 2007), 5 


\section{Sumber Data}

Jenis dan sumber data pada penelitian ini terbagi menjadi dua yaitu data primer dan data sekunder :

1. Data Primer

Data primer ini di peroleh dari sumber pertama sehingga data yang diolah oleh penulis yaitu dengan menganalisis tindakan atau perilaku yang terdapat pada video iklan layanan masyarakat "Stop Hoax". Penulis akan melihat dengan seksama Iklan tersebut dan memahami makna terhadap pesan moral yang terkandung dalam iklan pada tayangan di stasuin televisi Indosiar.

2. Data Sekunder

Data sekunder ini adalah data tambahan yang dapat diperoleh dari berbagai sumber. Datanya dapat situs, internet, serta sumber lainnya yang berkaitan dengan penelitian. Mulai mencari pencipta iklan Stop Hoax, pencetusnya, dan lain sebagainya yang berhubungan dengan judul penelitian.

\section{Teknik Pengumpulan Data}

Teknik pengumpulan data merupakan langkah yang paling utama dalam penelitian, karena tujuan dari penelitian adalah mendapatkan data. ${ }^{14}$

Pengumpulan data dapat dilakukan dalam berbagai sumber dan berbagai cara. Dilihat dari sumber datanya, maka pengumpulan data dapat menggunakan sumber primer dan sumber sekunder. Sumber primer merupakan sumber data yang langsung memberikan data kepada penggumpulan data sedangkan sumber sekunder merupakan sumber yang tidak langsung memberikan data kepada pengumpul data, misalnya melalui orang lain atau melalui dokumen.

Adapun teknik analisis data yang penulis gunakan untuk menganalisis iklan layanan masyarakat dalam tayangan stasiun TV Indosiar denga judul "Stop Hoax" yaitu menggunakan analisis semiotik dari John Fiske. Analisis semiotik Jhon Fiske memilik tiga level utama diantaranya realitas, representasi, dan ideologi. Dari tiga level ini penulis akan mengkaji lebih dalam sehingga muncul sebuah unit analisis penting yang terdapat dalam iklan "Stop Hoax". Unit analisis tersebut antaralain sebagai berikut:

${ }^{14}$ Sugiyono, Metode penelitian Kombinasi, (Bandung: Alfabeta,2015). h. 308 
Tabel. 1.1

\begin{tabular}{|l|l|}
\hline Level & Unit penelitian \\
\hline Realitas & Penampilan, lingkungan dan prilaku \\
\hline Representasi & $\begin{array}{l}\text { Kategori kamera, pencahayaan, dan } \\
\text { music }\end{array}$ \\
\hline Ideologi & $\begin{array}{l}\text { Ideologi yang dipakai dalam iklan } \\
\text { tersebut merupakan ideologi yang } \\
\text { berkaitan social atau sosialisme. }\end{array}$ \\
\hline
\end{tabular}

Untuk menganalisis video iklan ini, penulis menggunakan teknik alur maju mundur, dimana dalam iklan tersebut memiliki dua unsur utama dimana adanya teknik maju dan mundur dalam penayangannya. Sehingga dapat penulis simpulkan bahwa analisis ini ingin mengungkap pesan dari iklan 'Stop Hoax" dengan menganalisis iklan dan menelaah video tersebut secara seksama dengan teknik semiotik Jhon Fiske serta teknik alur maju mundur sebagai acuannya.

\section{Hasil Penelitian}

\section{Analisis pada Level Realitas}

Kode-kode social termasuk dalam level pertama ini, yakni meliputi appearance (penampilan), dress (kostum), make up (riasan), environment (lingkungan), behavior (prilaku), speech (cara berbicara), gesture (gerakan), dan expression (ekspresi).

\section{a. Level realitas kategori penampilan}

\section{Gambar 1.1}

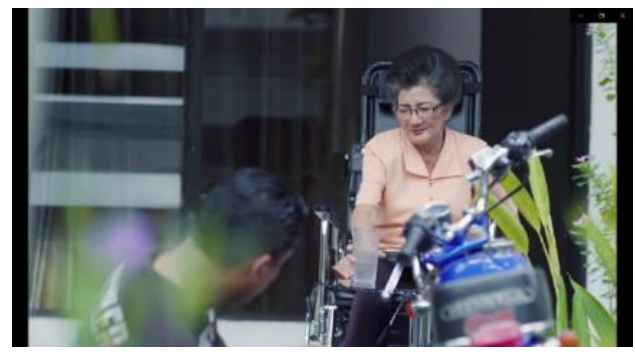


Terlihat dalam video iklan ada seorang ibu-ibu yang duduk di korsiroda. Menggunakan baju berwarna krem, berambut putih dan menngunakan kacamata. Dalam video iklan tersebut terlihat jelas ingin menggambarkan sosok wanita paruh baya yang hendak minum. Terlihat juga sosok pria yang menggunakan kaos berwarna hitam, sedang aksik membersihkan motornya, menggambarkan sosok anak muda.

\section{Gambar 1.2}

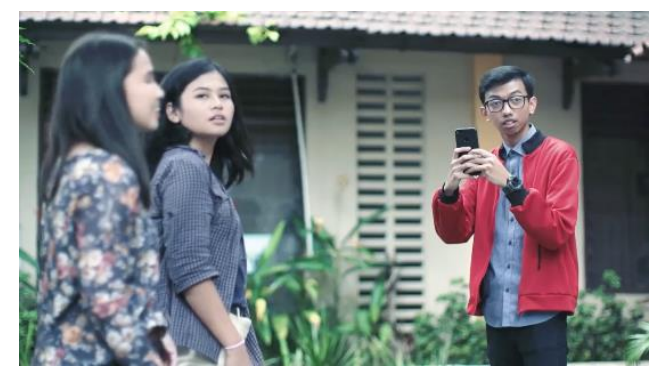

Pada gambar 1.2 terlihat tiga orang pemuda, dua berjenis kelamin perempuan dan satu laki-laki. Ketiga pemuda ini menggunakan pakaian yang santai, disana juga terlihat seorang pemuda laki-laki menggenggam Handphone dan hendak memfoto para wanita. Hal ini menunjukan bahwa kehidupan pemuda yang kerap mengekspresikan diri dengan berpakaian yang modern serta berfoto yang menjadi budaya untuk di abadikan setiap momen pertemuan.

\section{b. Level realitas kategori prilaku}

\section{Gambar 1.3}

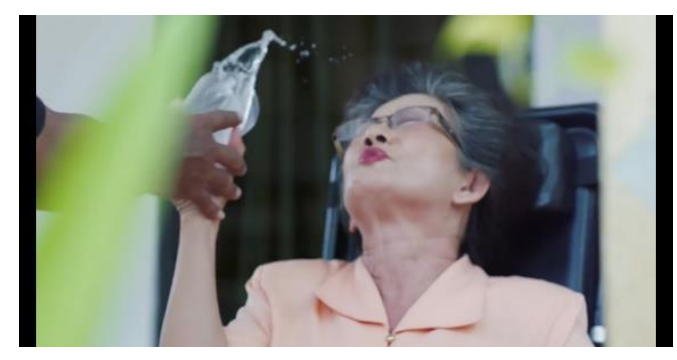

Melalui gambar ini dapat diketahui bahwa prilaku tercela yang dilakukan seorang anak kepada ibu. Terlihat seorang anak yang memukul tangan sang ibu yang hendak minum. Kemudian terlihat ekspresi sang ibu yang kaget dan langsung tersentak batuk. Namun sebenarnya prilaku yang ingin disamaikan dalam video iklan tersebut hanyalah kesalahpahaman. 


\section{Gambar 1.4}

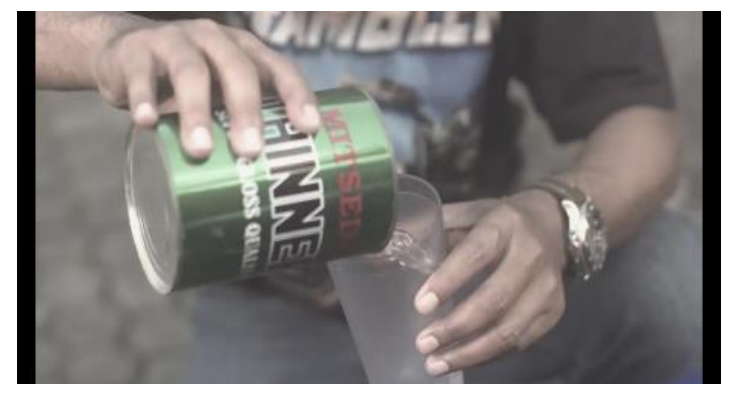

Pada gambar 1.4 terlihat sang anak yang menuangkan cairan terpenttin kendaraan kedalam gelas dan kemudian pada gambar 1.5 gelas berisi cairan terpentin diletakan di atas meja. Kedua gambar ini menjelaskan alur cerita dari pemukulan seorang anak kepada sang ibu agar tidak meminum air yang berisi cairan pembersih di atas meja. Video ini meberikan sebuah klarifikasi dari maksud pemukulan sang anak terhadap ibunya.

\section{Gambar 1.6}

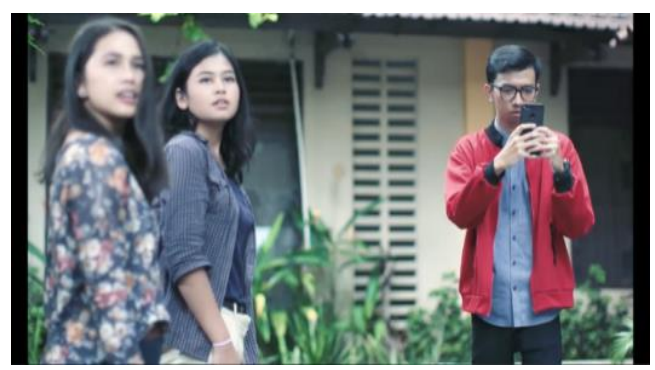

Pada gambar ini terlihat pemuda memakai jaket merah sedang serius merekam kejadian pemukulan seorang anak kepada ibu yang hendak minum. Dalam video bagaian ini memperlihatkan bagaimana handpone yang digunakan pemuda tersebut merekam tepat pada kejadian saat sang ibu hendak minum lalu sang anak mencegah dengan memukul tangan ibunya, terdapat dalam gambar 1.7. 


\section{Gambar 1.7}

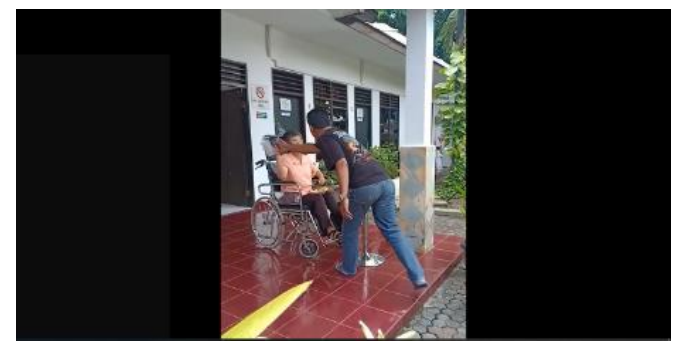

\section{c. Level realitas kategori lingkungan}

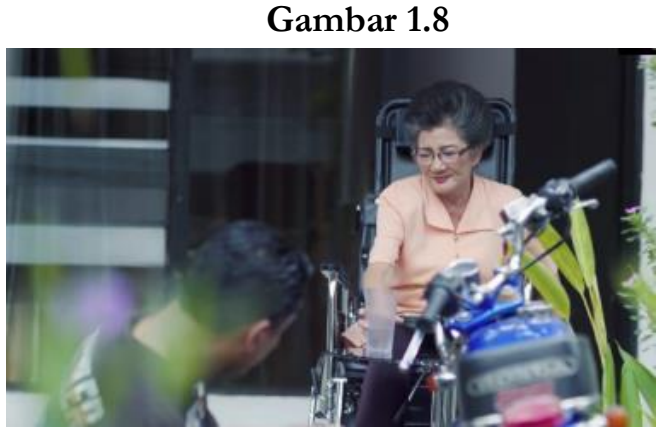

Pada katefori ini, iklan tersebut menunjukan bagaimana suasana keriuhan dipagi hari. Terlihat seorang ibu-ibu paruh baya yang sedang makan (sarapan pagi). Kemudian terlihat juga seorang pemuda laki-laki yang sedang membersihkan kendaraan roda dua nya. Hal inilah yang menunjukan bagaimana kondisi lingkungan yang menunjukan kesibukan masyarakat di pagi hari.

\section{Analisis pada Level Representasi}

Kode-kode yang termasuk dalam level kedua ini berkaitan dengan kode-kode tekik, seperti kamera, music, dan suara yang mentransmisikan kode-kode representasi konvensional, yang membentuk : naratif, konflik, aksi, dialog, setting, dan casting. 


\section{a. Level representasi kategori kamera}

\section{Gambar 1.9}
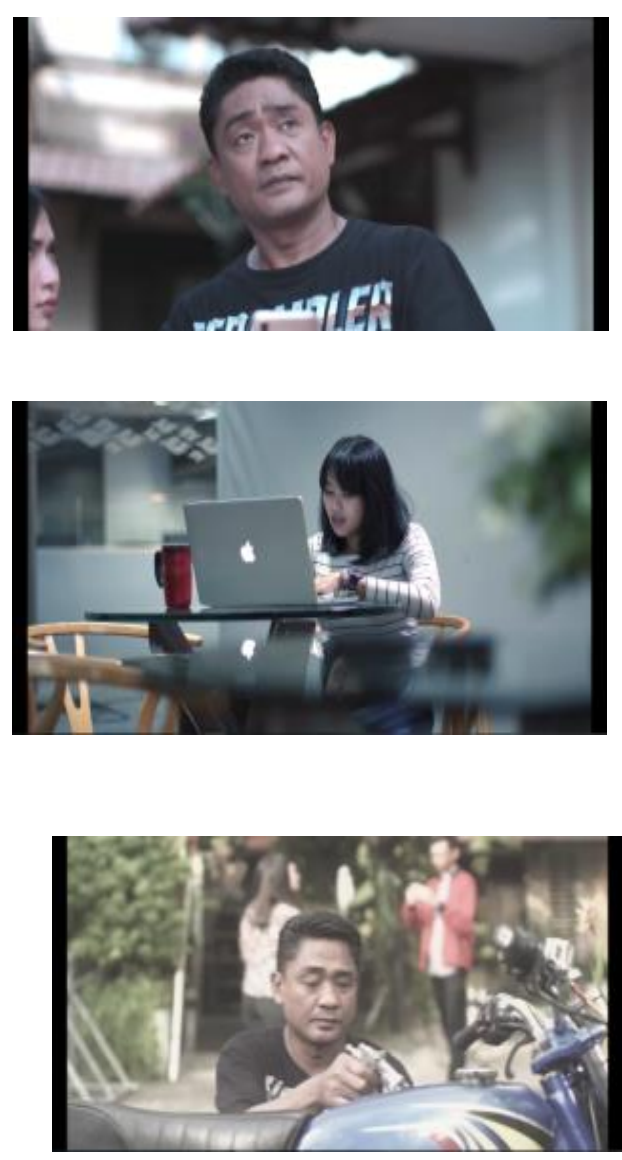

Pada gambar 1.9 yang terdiri dari 3 gambar, angel kamera yang digunakan gambar satu adalah teknik Long Shot atau Wide Shot. Dimana objek terlihat dekat namun dalam pengambilan gambar yang jauh dan lebih luas. Angel kamera pada foto kedua merupakan teknik pengambilan gambar Close up yaitu jenis pengambilan yang lebih memperlihatkan wajah secara detail. Teknik ini digunakan untuk memperlihatkan ekspresi wajah, senang atau sedih. Sedangkapn pada gambar ke tiga menggunakan teknik Mid Shoot teknik pengammbilan gambar sebatas kepala hingga pinggang, hal ini berfungsi memperlihatkan sosok objek secara jelas. 


\section{b. Kategori pencahayaan}

\section{Gambar 1.10}
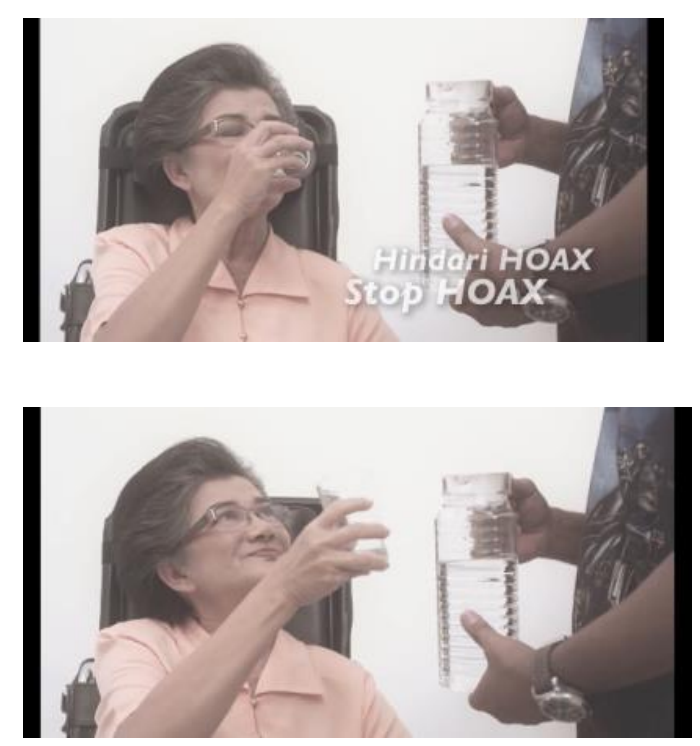

Pada gambar ini menggunakan pencahayaan low key, dimana untuk menghidupkan suasana dalam menceritakan ulang sebuah kejadian yang telah terjadi. Dan ini merupakan bentuk representasi dalam iklan untuk mengarahkan alur cerita. Sehingga dengan adanya pencahayaan yang berbeda pada bagian menceritakan kejadian yang sebenarnya, akan terlihat sisi perbedaan dari gambar saat kejadian dan saat di ulang. Pada level pencahayaan ini teknik analisis yang penulis ambil yaitu teknik analisis video dengan mode alur maju mudur.

\section{c. Kategori musik}

Pada iklan ini juga memberikan instrument music tegang, dimana dalam iklan tersebut bagaikan ada sebuah peristiwa yang mencekam. Kemudian ditambah ekspresi wajah dari sang ibu bagaikan kesakitan yang menambah kegaduhan. Di ending akhir iklan ini memasukan music selow. Mulai adanya klarifikasi dari peristiwa yang viral di media social hingga akhirya terselesikan. 


\section{Analisis pada Level Ideologi}

Pada level ini mencakup kode-kode representasi, seperti individualism (individualisme), patriarchy (patriarki), rece (ras), class (kelas), materialism (matrialisme), capitalism (kapitalisme) dan sosialisme .

\section{Gambar 1.11}
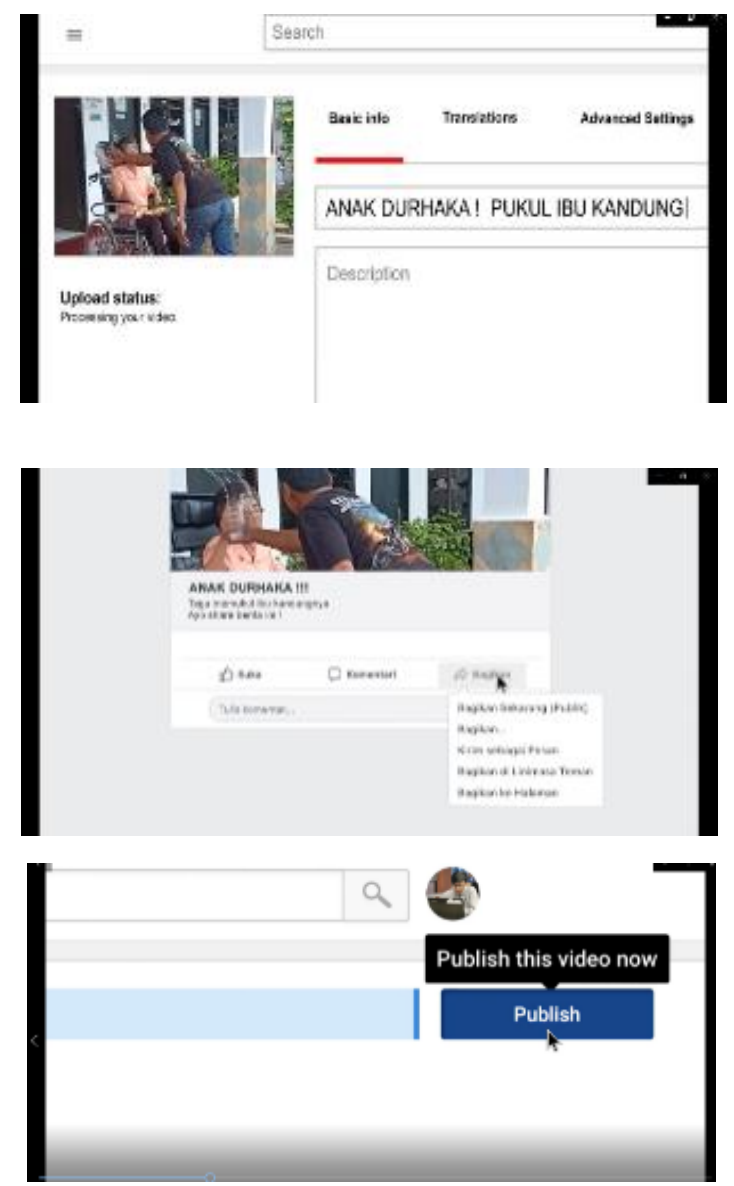

Pada gambar di atas terlihat tiga gambar yang memberikan informasi bahwa ketika sebuah berita dimuat ke media social, akan mudah tersebar luaskan dimana kecanggihan teknologi yang mumpuni membuat semakin lancarnya berita-berita hoax tersebar. Bagaimana tidak hanya dengan satu klik share/ bagikan video bisa viral tanpa di ketahui kebenarannya. Dan inilah yang menjadi problematika dewasa ini. Maraknya berita hoax yang membabi buta. Menyulitkan masyarakat untuk mendapatkan informasi yang rill. Harus adanya perubahan dari para konsumsi berita bahwa 
ideologi untuk menerima berita harus benar-benar di cari kebenarannya agar tidak menimbulkan konflik dan kesalah pahaman.

\section{Gambar 1.12}
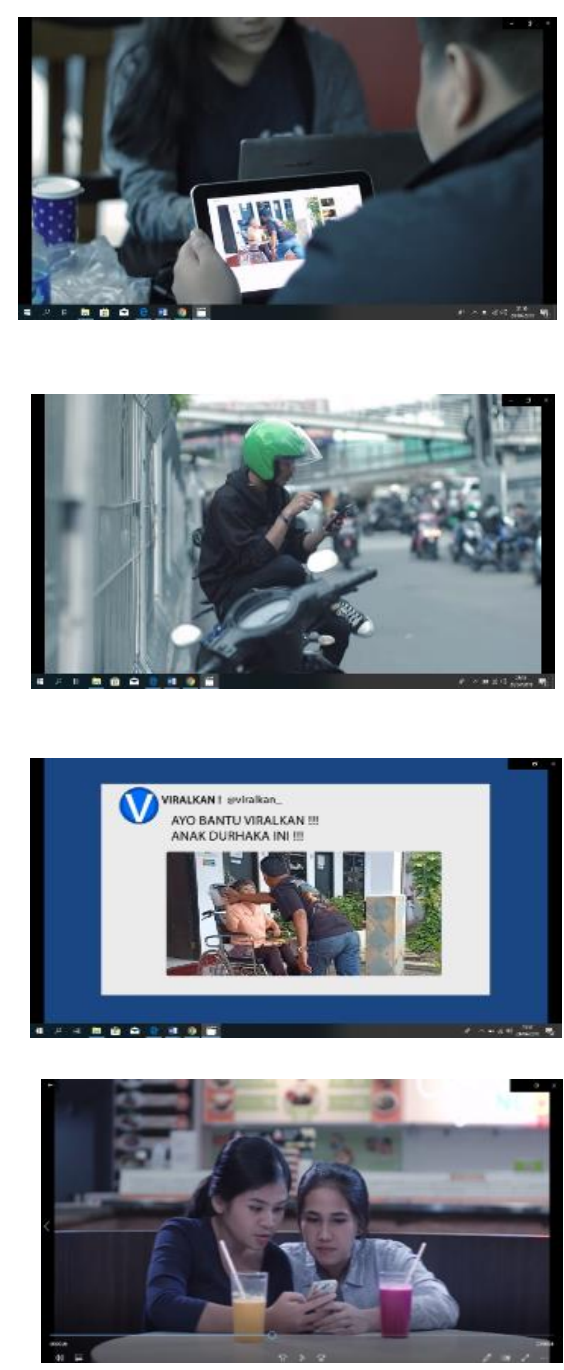

Pada gambar di atas melihat realita social dari dampak berita Hoax, gambar 1, 2 dan 3 terlihat bagaimana antusias masyarakat dalam mengkonsumsi berita hoax. Dalam hal ini mereka bukan hanya membagikan berita hoax, bahkan berkomentar di kolom akun media social dengan menjatuhkan sepihak. Seperti dalam gambar ke 4 terlihat akun media dengan nama akun Viralkan dimana terdapat caption "anak 
Durhaka" menambah kabar berita bohong yang seharusnya di cegah. Karena berita tersebut tidak sesuai dengan realita yang terjadi sebenarnya. Dampak berita hoax juga terlihat dari gambar berikut.

\section{Gambar 1.13}

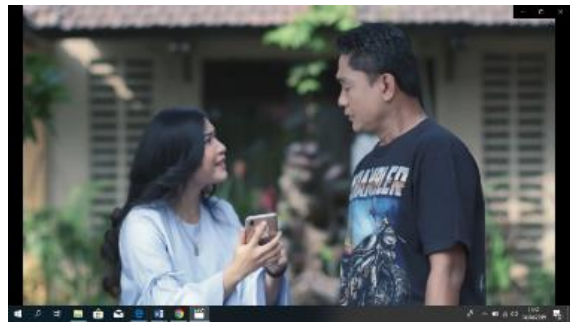

Dalam gambar tersebut terlihat seorang perempuan (istri ) memarahi laki-laki yang memukul ibunya (suami), efek dari berita hoax yang istri dapatkan dari media social. Sehingga menimbulkan konflik.

\section{Gambar 1.14}
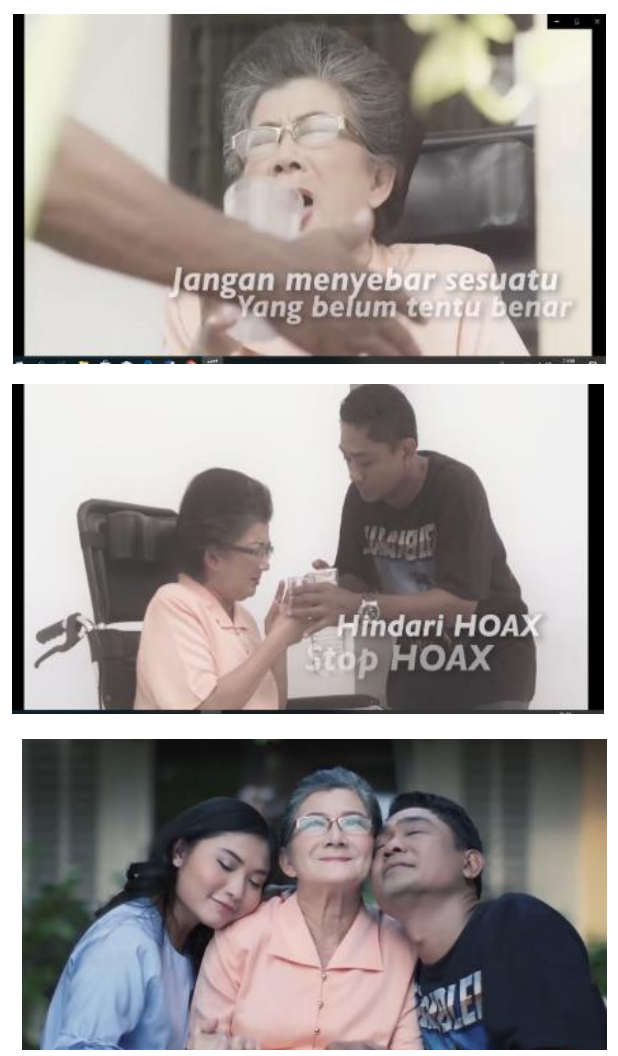
Dalam dialog pada gambar 1 dan 2 menunjukan adanya himbauan pada masyarakat agar tidak sembarangan dalam menyebar luaskan berita kebohongan. Karena dirasakan berita hoax akan menimbulkan dampak negative terlebih lagi bagi para orang awam yang baru mengenal dunia digital. Berita bohong juga dengan mudah menimbulkan konflik, baik ras, agama, budaya dan kelompok lainnya.

Sedangkan pada gambar ke 4 menjelaskan bahwa konflik bisa terselessaikan dengan damai. Jika adanya penjelasan dan klarifikasi dari peristiwa yang sebenarnya terjadi. Maka dari iklan Stop Hoax mengajarkan kita untuk saling menjaga, tidak saling tuduh apalagi benyebar berita bohong pada sesama. Gambar ke empat juga mengajarkan kedamaian dimana terdapat dua orang yang bersandar di bahu wanita paruh baya dimana gambar tersebut merepresentasikan agar bersikap patuh dan taat pada orang tua. Menjaga dan melindunginya.

Dari penjelasan pada level ideologi dapat penulis simpulkan bahwa ideologi yang digunakan oleh iklan tersebut yaitu berkaitan tentang sosialisme. Dimana ideology sosialisme merupakan sebuah paham yang mengutamakan kebersamaan sebagai tujuan hidup dan mengenyampingkan sikap individual.

\section{Penjelasan}

Berdasarkan iklan "Stop Hoax" yang dipersembahkan oleh Indosiar menggandung unsur mengenai maraknya pemberitaan kebohongan yang terjadi dewasa ini. Media indosiar membuat iklan layanan masyarakat yang sangat tepat karena saat ini maraknya berita kebohongan atau Hoax yang mudah di akses.

Dalam video iklan layanan masyarakat "Stop Hoax " pesan yang ingin disampaikan sangat mudah dipahami. Iklan yang mengandung unsur berita bohong ini menggambarkan bagaimana situasi dan kondisi masyarakat saat ini yang menyebar luaskan berita bohong dengan mudah, serta bagaimana keadaan masyarakat saat menanggapi berita yang viral padahal belum tentu kebenarannya.

Analisi semiotic Jhon Fiske dalam penelitian ini akan mengurai hasil penelitian yang meliputi tiga level. Pada level pertama yaitu realitas, pembahasan mengenai pakaian, lingkungan dan prilaku. Pada level rialitas pakian dan lingkungan, dalam iklan tersebut menampilkan sosok wanita paruh baya yang mengenakan baju krem, berkacamata kemudian duduk di kursi roda yang semakin terlihat jelas bahwa sosok wanita tersebut sudah tua. Kemudia terlihat juga sosok pria yang menggunaan kaos duduk didepan wanita paruh baya tersebut yang sedang asik membersihkan motornya. Suasana lingkungan pada iklan tersebut menggambarakan suasana pagi hari yang sibuk dengan aktivitas pagi. Di posisi lain, tepatnya di depan rumah ibu-ibu dan laki-laki yang sedang membersihkan motor terlihat juga 3 orang pemuda yang menggunakan pakaian trendi, sedang 
asik dengan getgednya menggambarkan bagaimana terknologi yang semakin canggih dizaman sekarang.

Sedangkan pada level realitas prilaku, dalam Iklan "Stop Hoax" menampilkan bagaimana pilaku seorang anak laki-laki yang sedang membersihkan motor tiba-tiba melihat sang ibu hendak minum lalu lakilaki tersebut memukul tangan ibu sehingga tertumhlah gelas yang ibu pegang serta sang ibu tersentak dan terbatuk. Adegan ini menggambarkan bagaimana sikap tercela seorang anak yang memukul ibunya dan dianggap sebagai anak durhaka. Disisi lain ada seorang pemuda yang merekam kejadian tersebut tepat saat sang anak memukul ibu dan ibu terbatuk dan tersentak kaget. Dalam realitas tersebut iklan ini ingin menjelaskan bahwa begitulah realita yang ada. Kondisi pemberitaan Indonesia saat ini, bahwa segala sesuatu yang di muat dalam media social belum tentu benar kebenarannya.

Level yang kedua adalah representasi angel kamera dan pencahayaan. Pada level angel kamera, iklan ini menunjukan bagai mana ekpresi seorang tokoh yang diperankan pemuda terlihat angel kamera close up pada bagain wajah, pria tersebut sedih ketika menyaksikan sebuah pemberitaan di media social yang mengatasnamakan dirinya dengan caption anak durhaka. Padahal berita yang tersebar di media social tersebut tidaklah benar.

Representasi kedua yaitu terletak pada pencahayaan. Dalam level ini, adanya dua unsur pencahayaan yang di pakai oleh iklan tersebut. Terlihat pada saat mengulang adegan, dimana adegan yang sebenarnya terjadi dari viralnya video yang tersebar di media social menggunakan cahaya low key. Cahaya ini ingin mempersentasikan bahwa kejadian sebenarnya terjadi adalah ketidak sengajaan seorang laki-laki memukul ibunya yang hendak meminum cairan pemberih motor.

Level ketiga yaitu Ideologi, dalam level ini ideology yang dipakai oleh iklan tersebut adalah sosialisme, dimana terlihat nilai-nilai moral yang ditampilkan dalam iklan tersebut. Seperti tindakan penyebar berita bohong, tindakan tercela dan kebijakan bersosial media. iklan tersebut ingin menggambarkan bagaimana kondisi social terutama dalam media. Melihat realitas yang terjadi memang iklan ini sanggat menggambarkan sesuai dengan fakta. Bahwa sekarang penyebar berita hoax ada di manamana demi popilaritas dan keuntungan semata. Untuk itu adanya kesadaran bahwa media social yang marak ini jangan sampai kita dikendalikan oleh hawa nafsu kejahatan. Bijaklah dalam bersosial media, berkarya dengan kebenaran bukan menyebar kebohongan.

Dari ketiga level ini semua saling berkaitan satu sama lain. Untuk membentuk sebuah pesan dalam iklan yang dimuat di media social memang harus didasari dengan pondasi yang kuat agar iklan yang disampaikan mampu di pahami dan dipraktikan oleh khalayak. 


\section{Kesimpulan}

Berdasarkan analisis semiotic Jhon Fiske terhadap iklan Layanan Masyarakat "Stop Hoax" memberikan gambaran melalui metode-metode yang di miliki Jhon Fiske. Dimana semiotika model John Fiske yang terdiri dari level realistas, repsentasi dan level idiologi. Hasil analisis tersebut sebagai berikut :

1. level realitas menggambarkan bagaimana suasana kesibukan pagi hari sehingga terjadi keteledoran hingga peristiwa ingin minum cairan pembersih kendaraan. Pada level ini menghasilkan bentuk ekspresi serta lingkungan perumahan.

2. Pada level representasi menggambarkan bagaimana pengambilan gambar yang signifikan, mulai pengambilan ekspresi hingga lingkungan. Kemudian ditambah backsound musik yang digunakan serta efek warna yang keseluruhan mempresentasi bagaimana kondisi yang terjadi dalam iklan tersebut dari kegaduhan hingga berakhir damai dan menghangatkan

3. Level ke tiga ideology, ideology yang di pakai dalam iklan tersebut adalah sosialisme bagaimana iklan mampu mengemas sebuah informasi dalam bentuk iklan layanan masyarakat. Mempresentasikan kondisi social dalam masyarakat terutama yang berkaitan tentang kebijakan dalam bersosial media agar tidak menyebar fitnah dan berita bohong yang merugikan orang lain.

\section{Daftar Pustaka}

Danesi Marcel, pengantar memahami semiotika media, (Ypgyakarta: Jalasutra,2017)

Eriyanto, Analisis Isi: Pengantar Metodologi untuk Penelitian Ilmu Komunikasi dan Ilmuilmu Sosial Lainnya, Jakarta: Kencana, 2011

Jafar lantowa, Nila mega marahayu, Muh.Kharussibyan, Semiotika teori,metode dan penerapannya, (Yogyakarta: CV Budi Utama, 2017)

Mulyana Dedy dan Solatun, Metode Penelitian Komunikasi, (Bandung: PT Remaja Rosdakarya, 2007)

Morissan, Jurnalistik Televisi Mutakhir, (Jakarta: Kencana, 2008)

Morissan, Wardhani Corry Andy, U Haid Farid, Teori Komunikasi Massa (media, budaya dan masyarakat, (Bogoor: Ghalia Indonesia,2013)

Sugiyono, Metode penelitian Kombinasi, (Bandung: Alfabeta,2015)

Ade Putri, "Representasi Agama dalam Iklan Indonesia adalah kita di NET.TV", ejurnal Ilmu Komunikasi, vol.55.2018 


\section{Internet}

https://tafsirq.com/49-al-hujurat/ayat-6 dimuat pada 2015

https://www.komunikasipraktis.com, dalam kajian komunikasi-massapengertian, pada /2015/04/.html

https://www.komunikasipraktis.com, dalam kajian komunikasi-massapengertian, pada /2015/04/.html 